Several small hunting spiders are to be found in the wasps nests which do not seem to leave any line behind then, and whose mode of life is very momadic. I quite believe from obser. vation that wasps can and do run these insects down by scent, although it is difficult to obtain direct proof of the fact. They seem quite capable of discerning between their prey and enemies, as shown above; and granting this, it does not seem a great stretch to a further development of instinct having the propagation of the species in view.

Can any of your readers explain to me in what manner the spiders are stupefied and not killed?

I have lately noticed cases of protective mimicry in birds which I think are worth recording.

While following a small wood-swallow (Artamus minor) a few evenings back, they suddenly disappeared near a large leaning gum-tree. Walking up to the spot they suddenly flew out of the trunk, which I found had been hollowed out by fire, leaving the inside charred and black. The bird 3 had chosen this black surface as their roost, and when followed in the day-time invariably flew into this refuge. It was impossible to detect the birds when clinging to the charred surface, with which their plumage matched.

Ariamus albiventris, I find, in like mamer chooses a greyish back as a roost against which they are less liable to be defected. Erythin ina wespertilio is a favourite tree with this species.

I have on several occasions taken Podargus gigantcus and other species alive by hand in broad daylight. These birds sit perfectly still on a limb of an iron-bark or acacia, whose bark resembles their plumage in colour.

Georgetown, Queensland, July I9

\section{Agricultural Ants}

I HAVE lately discovered a colony of agricultural ants near Georgetown. The species is very small and red.

$\mathrm{My}$ attention was first directed to these tiny harvesters by noticing heaps of chaff and hulls in a bare spot sizuated in a grove of young acacia trees.

The formicaries are entirely subterranean, being entered by a fumel-shaped tube.

Roads diverge from this gate in four or five directions, and during wrorking hours are alive with what appear like white insects, the little ants being covered by their load. Some of these ants seem to clean the grain and carry out the huslis, which form a heap round the opening to the nest. The clear space round each opening is small, certainly not more than eightecn inches in circumference, and a snall mound not more than six inches in height is formed with the earth excavated in forming the nest. The only species of grain harvested is the seed of Perotis rara, whch is light when quite ripe. I cannot give the generic name of these little fellows, never having devoted any special study to the family, but shall be happy to furnish specimens in spirits to any naturalist who will forward his address.

Dumobin, Georgetown, July 19

\section{Meteor}

AT about 5.50 P. M. to-day I saw a most brilliant meteor fall quite close to the moon, which was shining brightly at the time: it was in full daylight, shortly after the sum had gone down. Its direction was nearly perpendicular, but inclined a little from north to south as it fell. It was of a bright green colour; its motion rapid, its path long, and the time during which it was visible about two seconds, and it left no visible trace belhind it. Harlton, Cambridge, October 8 O. P. FISHER

\section{JANSSEN'S NEW METHOD OF SOLAR PHOTOGRAPHY}

$\mathrm{TN}$ two papers published respectively in the Comptes 1 Rendus for December, 1877, and in the Ammaire of the Bureau des Longitudes for the current year, M. Janssen bas described a new method of photographing the solar disc, which he has successfully carried out at the Meudon Observatory, during the past twelve months; and he has also drawn attention to some striking features in the constitution of the photosphere, disclosed for the first time in the beautiful pictures which are anong the first results of his process. These may be regarded as only the forerunners of further important discoveries. Through the courteous liberality of $M$. Janssen, $I$ have lately had the advantage of studying the process in the Meudon Observatory, and a description of its distinctive features, and a brief notice of such of the results as $M$. Janssen has already published, will certainly be acceptable to many who are interested in the recent developments of solar physics, and have not ready access to the original papers. ${ }^{1}$

M. Janssen's pictures of the solar disc are distinguished from all those previously obtained with the photoheliograph, not only by their great size $\left(30^{\circ} 5 \mathrm{ctm}\right.$. diameter), but more especially by the remarkable sharp. ness and definition with which they display the details of photospheric structure, which are such that, for the purpose of their more effective study, it is found advantageous to enlarge the original pictures to three and even nine times their original linear dimensions. The greatly extended means of research which $M$. Janssen's invention places in the hands of the solar physicist will be obvious, when we consider the difficulties which attend any prolonged ocular inspection of the solar disc, hitherto the only practicable method of examining its detailed structure. "In spite of the interposition of coloured glasses, helioscopes, \&c., the eye must seize on the details in a dazzling field, and perform its functions under conditions which are quite unfamiliar. The true variations of luminous intensity in different parts of the imase can no longer be appreciated, and the impressions produced do not correspond to reality. Thus may be explained the diversity of the opinions which have been put forward respecting the forms and dimensions of the granulations, and of the constituent parts of the solar surface"-diversities well illustrated by the old controversy of the "willow-leaf" and "rice-grain" bodies in the photosphere. In M. Janssen's pictures the forms, sizes, and arrangement of the bodies described under these appellations are exhibited in the most satisfactory manner, and as, in a farourable state of the atmosphere, the pictures may be repeated at as short intervals as the operator pleases, the movements and changes of form exhibited by these bodies may be studied with the utmost ease in a register which preserves the most fugitive phases of their appearance, and is available for leisurely re-examination at any future time.

Before noticing the novel facts which $M$. Janssen has thus brought to light, I will briefly describe the principles of the process itself. The main difficulty to be surmounted in order to obtain a sharply defined photographic picture of the details of the solar disc is presented by the phenomenon known as photographic irradiation, in virtue of which a brilliantly illuminated surface occupies, on the negative picture, a proportionally exaggerated space ; its borders being extended over the darker objects around. This phenomenon, M. Janssen remarks, "is very striking in all the photographs of total eclipses which have been obtained since I 860 , which exhibit the images of the protuberances encroaching on the lunar disc, to the extent, in some cases, of ten and twenty seconds of arc, and even more." The granulations (to employ M. Jarssen's terminology) visible on the solar disc have a mean diameter of not more than one second of arc, and in ordinary photoheliograms their very existence is therefore completely masked by irradiation.

I The present notice contains a moxe detailed descripticn of the process than M. Janssen's original papers, and is published with his full approval and authority. With characteristic liberality M. Janssen writes:- "Quant au procédé lui-même, il est evident que toute persunne un feu au courant de la photegraphie astronomique pourra l'appliquer et obtenir bientôt des photographies semblables à celles que nous obterons. Je serai aussi très probablement devancé sur plusieurs points cle la censtituticn du soleil que ces prccédés peivent révéler. L'incunvenient n'est que pour moi, et je crois gu'il vaut mieux des aujourd'hui liver la méthcde, au public scientifique. Les frogrés de la science $y^{r}$ gagnercnt certaireme: $t$." 